\title{
Playing-Related Musculoskeletal Disorders of \\ Professional Orchestra Musicians from the North of \\ Portugal: Comparing String and Wind Musicians
}

\author{
Alterações Musculoesqueléticas dos Músicos de \\ Orquestras Profissionais do Norte de Portugal: \\ Comparação entre Instrumentistas de Cordas e Sopros
}

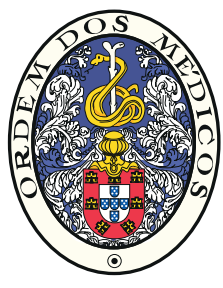

\author{
Cláudia Maria SOUSA ${ }^{1}$, Jorge Pereira MACHADO ${ }^{1}$, Henry Johannes GRETEN ${ }^{1}$, Daniela COIMBRA ${ }^{2}$ \\ Acta Med Port 2017 Apr;30(4):302-306 - https://doi.org/10.20344/amp.7568
}

\section{ABSTRACT}

Introduction: It is well known that musicians are a group prone to suffer from playing-related musculoskeletal disorders. Professional orchestra musicians play for several hours a week and have to fight against pain caused by their profession. The aim of this study was to explore and describe self-reported complaints among professional orchestra musicians and to compare its intensity and the prevalence between string and wind instruments.

Material and Methods: Hundred and twelve professional orchestra musicians from the three main professional orchestras from the North of Portugal were individually interviewed about the prevalence and the intensity (measured by verbal numerical scale for pain) of their playing-related musculoskeletal disorders.

Results: About two third (62.5\%) of the interviewed musicians presented playing-related musculoskeletal disorders during the time of the interview. Despite there are no significant statistic values between groups, results suggested that playing-related musculoskeletal disorders are more common in string players and more intense in wind players.

Discussion: Referring to the prevalence of playing-related musculoskeletal disorders, our data is in line with other studies from different countries. More than half of professional orchestra musicians in the North of Portugal are playing with a mild to moderate pain. Conclusion: Future studies focusing on working-related problems among professional orchestra musicians in Portugal would be useful to better describe the problem of occupational diseases among performing artist.

Keywords: Musculoskeletal Diseases; Musculoskeletal Pain; Music; Occupational Diseases; Portugal

\section{RESUMO}

Introdução: A literatura estabelece claramente que os músicos são um grupo com elevado risco de desenvolvimento de lesões músculoesqueléticas relacionadas com o trabalho. Os músicos profissionais de orquestra trabalham semanalmente durante várias horas e deparam-se frequentemente com a dor como consequência da sua profissão. O presente estudo pretende descrever a prevalência e a severidade das lesões músculoesqueléticas relacionadas com o trabalho que afetam os músicos de orquestras profissionais do Norte de Portugal, comparando instrumentistas de cordas e de sopros.

Material e Métodos: Cento e doze músicos das três orquestras profissionais do Norte de Portugal foram entrevistados individualmente de forma a determinar a prevalência e a intensidade da dor (medida pela escala verbal numérica de dor) das suas lesões músculoesqueléticas relacionadas com o trabalho.

Resultados: Aproximadamente dois terços (62,5\%) dos músicos entrevistados apresentaram lesões músculoesqueléticas relacionadas com o trabalho durante a entrevista. Apesar de não se verificarem diferenças estatisticamente significativas, os resultados obtidos sugerem que as lesões músculoesqueléticas relacionadas com o trabalho são mais frequentes nos instrumentistas de cordas e mais intensas nos instrumentistas de sopro.

Discussão: Os resultados referentes à prevalência de lesões músculoesqueléticas relacionadas com o trabalho são similares a resultados de outros estudos realizados em diferentes países. Mais da metade dos músicos de orquestras profissional no Norte de Portugal apresentam diariamente dor leve a moderada.

Conclusão: Verifica-se a necessidade de realização de investigações futuras com o objetivo de estudar com maior profundidade os problemas profissionais que afetam os músicos em Portugal.

Palavras-chave: Doenças Musculoesqueléticas; Doenças Ocupacionais; Dor Musculoesquelética; Música; Portugal

\section{INTRODUCTION}

It is well known that musicians are frequently affected by specific professional diseases like playing-related musculoskeletal disorders (PRMD). ${ }^{1}$ Constant and repetitive movements performed without ergonomic precautions in combination with self-imposed pressures, make musicians a vulnerable group to suffer from working-related diseases. ${ }^{2}$ Research shows a high prevalence of PRMD that can affect musicians seriously enough to influence the peak of their career. ${ }^{3}$ In fact, almost half of the musicians experience playing-related medical problems that could threaten or end their careers. ${ }^{4}$ The prevalence of playing-related musculoskeletal disorders is well documented. Studies from Zaza (1998) state that the percentage of affected musicians ranged from $39 \%$ to $87 \%$. More recent data states that the

1. Laboratório de Fisiologia Aplicada. Instituto de Ciências Biomédicas Abel Salazar. Universidade do Porto. Porto. Portugal.

2. Conselho Técnico-Científico e Pedagógico. Escola Superior de Música e Artes do Espetáculo. Universidade do Porto. Porto. Portugal.

$\triangle$ Autor correspondente: Cláudia Maria Sousa. claudia.sousa@ua.pt

Recebido: 26 de fevereiro de 2016 - Aceite: 24 de janeiro de 2017 | Copyright @ Ordem dos Médicos 2017 
percentage of affected musicians varies between $64 \%$ and $94 \% .^{5-9}$

Common PRMD of musicians include overuse complaints, entrapment neuropathies and occupational hand cramp $^{10}$ that frequently affect the upper part of the body including neck, shoulder, arm and wrist. ${ }^{11-13}$ Those injuries can cause symptoms ranging from slight to severe pain. ${ }^{4}$ Individual technique, musician characteristics e.g. age and gender, the repertoire, study habits and years of playing experience, psychological stressors, lack of preventive wellness behaviours, previous trauma, environmental conditions and other variables could contribute to the development of PRMD. ${ }^{14-17}$

The instrument type also seems to contribute to the onset of PRMD. ${ }^{18}$ The instrument's weight and the imposed posture could influence the prevalence of musculoskeletal injuries among musicians. ${ }^{14}$ Studies about the lateralization of upper extremity disorders in instrumentalists showed that string, woodwind and brass instrumentalists present a different prevalence of injuries in different sides of the body. ${ }^{9}$ Research also shows that instruments imposing asymmetric postures e.g. violin, viola, flute, and others also contribute to the assuming of unhealthy postures by the musician. ${ }^{19}$ Musicians playing in an elevated arm position are also more prone to suffer from PRMD in the upper limb than musicians playing in a neutral arm position. ${ }^{20}$

There are several research studies around the world about the prevalence of PRMD among string and wind musicians. Studies from Lockwood ${ }^{4}$ concluded that string players are the most commonly affected by musculoskeletal disorders and percussionists the least. Recent studies are not completely conclusive about which instrument group is the most prone to suffer from PRMD. Some authors affirm that string instrumentalists are more prone to suffer from $\mathrm{PRMD}^{9,21}$ and wood wind players the least ${ }^{22}$ but in contrast Llobet $^{8}$ (2004) affirms that percussionists are the most affected by PRMD, followed by wind and string players.

Musicians frequently tend to underestimate their problems, ignoring pain and symptoms requiring treatment or rest. ${ }^{23}$ The recommended time of rest ranged from two to seven days depending on the complaints. ${ }^{24}$ Approximately one third of the affected musicians have to stop playing during a period of time. ${ }^{3}$ Frequently, when the disease appears, musicians try to deal with it, without asking for help to their colleagues. This behaviour could be explained by the fear of losing the workplace and of course the implication and recommendation to stop playing. ${ }^{8}$

To our knowledge, the epidemiology of PRMD among musicians has never been studied in professional Portuguese orchestras. The aim of this study was to explore and describe self-reported complaints among professional orchestra musicians and to compare its intensity and the prevalence between string and wind instruments. Due to geographic convenience only orchestras from the North of Portugal were considered.

\section{MATERIAL AND METHODS}

Due to geographic convenience 162 professional orchestra musicians from the three main professional orchestras of the North of Portugal (Orquestra Sinfónica do Porto Casa da Música, Orquestra Filarmónica das Beiras and Orquestra do Norte) were asked to take part into this observational epidemiological study. Of those, 112 agreed to participate and the participation rate was consequently of $69.6 \%$. Only musicians working in full time in the selected orchestras were invited to participate and therefore included. In an individual semi-structured interview, done within the orchestra installations, PRMD and its intensity (measured by verbal numeric scale-VNS) were registered. Only playing-related injuries diagnosed by a physiotherapist were considered. Only symptoms present during the time of the interview, capable to be evaluated, were considered. The data was collected between September of 2012 and June of 2013.

This study was performed after the Ethical approval from the Institute of Biomedical Sciences Abel Salazar University of Porto. All the participants signed and gave their informed consent according to the Helsinki declaration.

\section{Measurements}

The verbal numeric scale (VNS) for pain intensity is one of the most frequently scales used to evaluate pain intensity. Patients estimate their pain on a scale from 0 to $10,{ }^{25}$ where 0 represents no pain, 1 to 3 represents mild pain (nagging, annoying, little interference with activities of daily life), 4 to 6 represents moderate pain (interferes significantly with activities of daily life) and 7 to 10 represents severe pain (unable to perform activities of daily life). This scale can be used with adults and children ( $>9$ years old) and in all patients able to use numbers to rate the intensity of their pain. ${ }^{26}$ The significance of the verbal numeric scale was studied by Holdgate et $a^{27}$ in 2003 , and the authors concluded that VNS is a valid instrument to assess changes in pain intensity

\section{Data analyses}

VNS values were analysed using SPSS (version 21.0, SPSS Inc., Chicago, Illinois, USA). The Mann-Whitney test was performed to analyse the difference in VNS values between string and wind musicians, and within wind players

Table 1 - Sample characteristics

\begin{tabular}{lcccc} 
& $\mathbf{n}$ & Male & Female & Age \\
\hline Total & 112 & 75 & 37 & $37.8(\mathrm{SD}=9.4)$ \\
String players & 71 & $40(56.0 \%)$ & $31(44.0 \%)$ & $37.7(\mathrm{SD}=9.8)$ \\
Wind players & 37 & $31(83.8 \%)$ & $6(16.2 \%)$ & $36.2(\mathrm{SD}=9.0)$ \\
\hline
\end{tabular}


- metal and wood. The Kruskal-Wallis test was used to compare VNS values within string players - $1^{\text {st }}$ violins, $2^{\text {nd }}$ violins, violas, cellos and doblebasses. ${ }^{28}$

\section{RESULTS}

\section{Sample characteristics}

Table 1 shows the sample characteristics and the distribution of musicians according to instrument, age and gender.

\section{Self-reported complaints}

Out of the 112 involved, $70(62.5 \%)$ claimed to have PRMD during the time of the interview. Table 2 shows the number of affected musicians and their complaints.

As the number of percussionists is too small, it will not be considered in this analysis. Table 2 shows that string players are the most frequently affected by PRMD with $67.6 \%$ of affected musicians against $54.1 \%$ of wind players. Results also show that the number of complaints per musician is higher in string instruments (1.2 complaints per musician) than in wind musicians ( 0.9 complaints per musician). Analysing the number of complaints per affected musician, data shows a minimal difference between groups.

Considering data within string instrumentalists results shows that first violins are the most frequently affected by PRMD with an average of $81.2 \%$, followed by violas $(78.6 \%)$, second violins $(69.8 \%)$, double bass $(54.5 \%)$ and cello players $(46.2 \%)$. Nevertheless the number of complaints per musician and the number of complaints per affected musicians is higher among the second violins (1.7 and 2.5 respectively). As far as wind instruments are concerned, results show that brass wind players are more affected $(60 \%)$ and present more complaints per musician (1) than wood players. The difference between the number of complaints per musician and the number of complaints per affected musician is almost nil.

\section{Pain intensity - VNS values}

During the interview, musicians subjectively measured their pain using VNS. Table 3 shows the means of those values.

Comparing data for string and wind players results show that wind instrumentalists self-reported higher pain intensities than string players, however this is not a significant value ( $p$ value $=0.328$ )

Within string instruments, viola players are the most affected with highest pain intensity (VNS $=5$ ). They are followed by the first violins (VNS $=4.4$ ), the cellos (VNS = 4.4 ), the double bass players (VNS $=4.2$ ) and second violins (VNS = 3.8). Comparing values, this is not a significant difference $(p$ value $=0.703)$.

Within the wind instruments group, there are no differences in pain intensity between brass and wood instruments $(p$ value $=0.606)$.

\section{DISCUSSION}

Results show that $62.5 \%$ of the interviewed musicians suffer from acute PRMD with an average of from 5 to 3.8 VNS. This result is astonishing since the participants are still playing in the orchestra. Those data demonstrate that more than half of professional orchestra musicians in the North of Portugal are playing with a mild to moderate pain. Maybe they are used to pain because they live in such a competitive environment that they cannot stop playing. According to Llobet, ${ }^{8}$ musicians try to deal with their working-related problems in secret because they fear stopping playing and consequently losing their jobs.

Due to the low number of percussion players, our data just allows a comparison between string and wood instruments. Results show that string players $(67.1 \%)$ are more affected by PRMD than wind players (54.1\%). Our results are in line with the conclusions of Lockwood, ${ }^{4}$ Lederman, ${ }^{9}$ Heming ${ }^{3}$ and Cohen and Ratzon. ${ }^{21}$ VNS values

Table 2 - Self-reported complaints according to instrument type

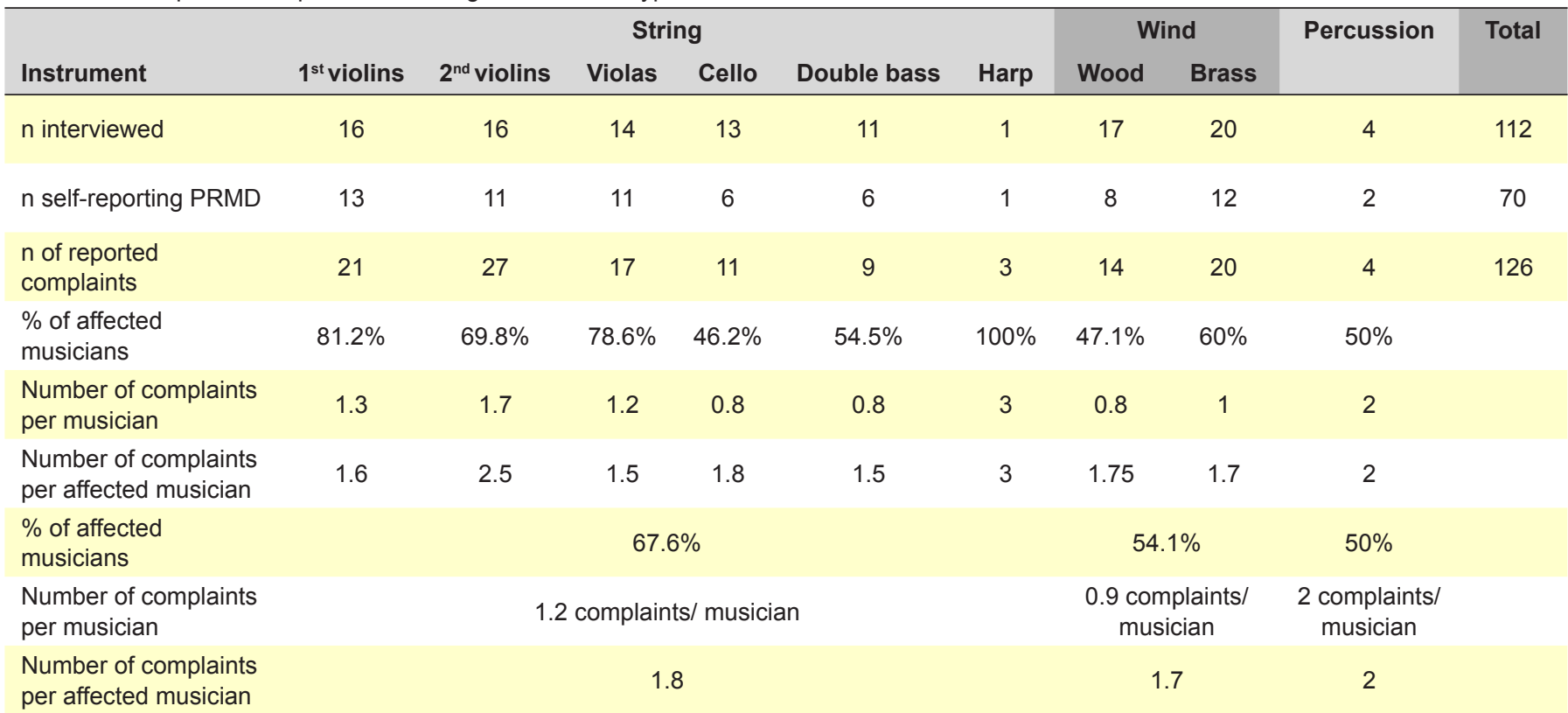


Table 3 - Pain intensity measured by VNS

\begin{tabular}{lcccccccc}
\hline & 1 $^{\text {st }}$ violins & 2 $^{\text {nd }}$ violins & Violas & Cello & Double bass & Wood & Brass & Percussion \\
\hline Mean & 4.4 & 3.8 & 5.0 & 4.4 & 4.2 & 4.7 & 4.7 & 5.3 \\
Standard deviation & 2.3 & 2.1 & 1.9 & 1.0 & 1.6 & 2.0 & 2.1 & 3.2 \\
$p$ value & & & 0.703 & & & & 0.606 & small sample size $(\mathrm{n}=4)$ \\
Mean & & & 4.3 & & & 4.7 & \\
Standard deviation & & & 1.9 & & & & & \\
$p$ value & & & & 0.328 & & & & small sample size $(\mathrm{n}=4)$ \\
\hline
\end{tabular}

suggest that wind players present more intense pain than string instrumentalists (4.3 VNS in string players and 4.7 VNS in wind players). This perhaps indicates that, although this is not statistically significant, wind players present more intense complaints and string players are more prone to suffer from PRMD.

Within string players, results show that musicians playing first violin are the most affected followed by violas and second violins. According to Nyman et al, ${ }^{20}$ musicians playing in an elevated arm position are more prone to suffer from PRMD than musicians playing in a neutral arm position. This perspective explains why violins and violas are more affected than double bass and cello instrumentalists.

Regarding pain intensity within the group of string players, violas presented the highest VNS values. Studies report that individual technique, the musician's characteristics and the instrument itself could influence the appearance of PRMD. ${ }^{14-16,22}$ The weight of the instrument and the asymmetric posture imposed by the instrument type also contribute to the appearance of PRMD. ${ }^{14}$ Despite the fact that viola players assume an asymmetric posture which makes them prone to suffer from PRMD, they have to face the weight of the instrument. A viola is heavier than violin and this minor aspect may influence the intensity of PRMD.

Within the wind players group, brass winds are more frequently affected by PRMD (60\%) than wood wind players (47.1\%). Paarup et $a^{22}$ also concluded that wood wind players are the less affected by PRMD. We can again report that metal instruments are heavier than wood instruments and maybe this fact can explain our data. ${ }^{14}$ In terms of pain intensity, there are no differences between them.

\section{CONCLUSION}

To our knowledge this is the first study comparing the intensity and prevalence of PRMD among wind and string musicians of professional orchestras in Portugal. While our study covers all the professional orchestras from the North of Portugal, the Centre region, as well as the Southern area and the Islands are still missing in this research. In the same way, participation rate is $69 \%$. Those facts also limit our conclusions

\section{REFERENCES}

1. Ostwald P, Baron B, Byl N, Wison FR. Performing arts medicine. West J Med. 1994;160:48-52

2. Zaza C. Playing-related musculoskeletal disorders in musicians: a systematic review of incidence and prevalence. Canad Med Assoc J.
Pain intensity is always difficult to measure. VNS values are from subjective pain perception that changes according to the individual characteristics of the person. Our results must be analysed considering this limitation. VNS is simple to use and it does not consume many time, which is why we choose it to measure subjective pain intensity in this research.

According to our results, approximately two thirds of professional orchestra musicians from the North of Portugal suffer from PRMD. Pain is more prevalent in string players but more intense in wind players. Although our results could not be generalized, we hope to raise awareness of the importance of PRMD among professional orchestra musicians in Portugal. While this is a very common theme all over the world, Portuguese society is not aware of the problems of performing artists.

Future studies focusing on working-related problems among professional orchestra musicians in Portugal would be useful to better describe the extent of the problem and the type of occupational diseases among performing artists in Portugal.

\section{PROTECTION OF HUMANS AND ANIMALS}

The authors declare that the procedures were followed according to the regulations established by the Clinical Research and Ethics Committee and to the Helsinki Declaration of the World Medical Association.

\section{DATA CONFIDENTIALITY}

The authors declare having followed the protocols in use at their working center regarding patients' data publication.

\section{CONFLICTS OF INTEREST}

The authors declare that there are no conflicts of interest.

\section{FUNDING SOURCES}

No subsidies or grants contributed to this work

1998;158:1019-25

3. Heming M. Occupational injuries suffered by classical musicians through overuse. Clin Chiropractic. 2004;7:55-66.

4. Lockwood M. Medical problems of musicians. $\mathrm{N}$ Eng $\mathrm{J}$ Med. 
$1987 ; 320: 221-7$.

5. Leaver R, Harris E, Palmer T. Musculoskeletal pain in elite professional musicians from British symphony orchestras. Ocup Med. 2011;61:549_ 55.

6. Kaneko Y, Lianza S, Dawson W. Pain as an incapacitating factor in Symphony Orchestra musicians in São Paulo, Brazil. Med Probl Perform Art. 2005;20:168-74.

7. Oliveira C, Vezzá F. Musicians' health: pain resulting from playing musical instruments among members of orchestras of the ABCD region, São Paulo. Rev Bras Saude Ocup. 2010;35:33-40.

8. Llobet R. Musicians' health problems and their relation to musical education [Internet]. Barcelona and Tenerife: XXVI Conference of the International Society for Music Education \& CEPROM Meeting, 2004 [consulted 2015 Feb 10]. Available from: http://institutart.com/index./ $\mathrm{ca} /$ divulgacio/item/musicians-health-problems-and-in-their-relation-tomusical-education

9. Lederman R. Neuromuscular and musculoskeletal problems in instrumental musicians. Muscle Nerve. 2003;27:549-61.

10. Joubrel I, Robineau S, Petrilli S, Gallien P. Musculoskeletal disorders in instrumental musicians: epidemiological study. Ann Readapt Med Phys. 2001;44:72-80.

11. Kok L, Vlieland T, Fioco M, Nelissen RG. A comparative study on the prevalence of musculoskeletal complaints among musicians and nonmusicians. BMC Musculoskelet Disord. 2013;14:1-9.

12. William J. Upper-extremity problems caused by playing specific instruments. Med Probl Perform Art. 2002;17:135.

13. Bird H. Overuse syndrome in musicians. Clin Rheumatol. 2013;32:4759 .

14. Frank A, Mühlen C. Playing-related musculoskeletal complaints among musicians: prevalence and risk factors. Rev Bras Reumatol. 2007; 47:188-96.

15. Fragelli T, Carvalho G, Pinho D. Musicians' injuries: when pain overcomes art. Rev Neurocienc. 2008;16:303-9.
16. Wu S. Occupational risk factors for musculoskeletal disorders in musicians: a systematic review. Med Prob Perform Art. 2007;22:43.

17. Sousa C, Machado J, Greten H, Coimbra D. The prevalence of playingrelated musculoskeletal disorders (PRMSD) among professional prchestra players. Rev Música Hodie. 2014;14:111-21.

18. Steinmetz A, Seidel W, Muche B. Impairment of postural stabilization systems in musicians with playing-related musculoskeletal disorders. J Manipulative Physiol Ther. 2010;33:603-11.

19. Ramella M, Fronte F, Rainero G. Postural diseases in conservatory students: The Dieses Project. Med Probl Perform Art. 2014;29:19.

20. Nyman T, Wiktorin C, Mulder M, Johansson YL. Work postures and neck-shoulder pain among orchestra musicians. Am $\mathrm{J}$ Ind Med. 2007;50:370-6.

21. Cohen Y, Ratzon N. Correlation between risk factors and musculoskeletal disorders among classical musicians. Occup Med. 2011;61:90-5.

22. Paarup H, Baelum J, Holm J, Manniche C, Wedderkopp N. Prevalence and consequences of musculoskeletal symptoms in symphony orchestra musicians vary by gender: a cross-sectional study. BMC Musculoskel Disord. 2011;12:223.

23. Suskin E, Schachter E, Kolčić I, Polašek O, Mustajbegović J, Arumugam $U$. Health problems in musicians - a review. Acta Dermatovenerol. 2005;13:247-51.

24. Heinan M. A review of the unique injuries sustained by musicians. JAAPA. 2008;21:45-51.

25. Sousa FF, Silva JA. The metric of pain: theoretical and methodological issues. Rev Dor. 2005;6:469-513.

26. Mccaffery M, Beebe A. Pain: clinical manual for nursing practice. Missouri: Mosby Company; 1993.

27. Holdgate A, Asha S, Craig J. Comparison of a verbal numeric rating scale with the visual analogue scale for the measurement of acute pain. Emerg Med. 2003;15:441-6.

28. Fortin M. O processo de investigação: da concepção à realização. Loures: Lusociência; 1999. 